\title{
Stereospecific Degradation of Diastereomers by Plant Associated Bacteria Influences the Antifungal Performance of Dodemorph*
}

\author{
Gyula Oros \\ Plant Protection Institute, Hungarian Academy of Sciences, Budapest, Hungary \\ Email: gyula.oros@gmail.com
}

How to cite this paper: Oros, G. (2018) Stereospecific Degradation of Diastereomers by Plant Associated Bacteria Influences the Antifungal Performance of Dodemorph. Journal of Agricultural Chemistry and Environment, 7, 10-20.

https://doi.org/10.4236/jacen.2018.71002

Received: December 14, 2017

Accepted: January 22, 2018

Published: January 25, 2018

Copyright $\odot 2018$ by author and Scientific Research Publishing Inc.

This work is licensed under the Creative

Commons Attribution International

License (CC BY 4.0).

http://creativecommons.org/licenses/by/4.0/

\section{(c) (i) Open Access}

\begin{abstract}
Morpholine fungcides have certain antibacterial side effect, dodemorph being the most active among them. The diequatorial (cis-) form of dodemorph expressed higher antibacterial activity than the axial-equatorial (trans-) form, and no synergy in their joint action could be revealed in this respect. Moreover, the partition of diastereomers between cells and medium strictly correlated to their toxicity. Considerable differences were detected among degradation rates in various bacteria, and the meso-(RS)-diastereomer was deteriorated more intensively, then the trans-( $S S$ and $R R$ )-forms in Corynebacterium betae, Erwinia uredovora and Pseudomonas fluorescens. As a result, the stereospecific degradation of diastereomers changed their ratio in the medium, thus this metabolic step could influence the antifungal performance of dodemorph based preparations against filamentous fungi. It was demonstrated that due to synergic joint action, the fungistatic effect of morpholine derivatives noticeably increased against Botrytis cinerea by changing the ratio of diastereomers.
\end{abstract}

\section{Keywords}

Fungicide, Diastereomer, Biodegradation, Bacteria, Fungi, Synergy, Stereoselectivity

\section{Introduction}

The morpholine derivatives have been introduced against powdery mildews [1]. These compounds inhibit steroid biosynthesis [2] [3] and lipid peroxidases [4] ${ }^{*}$ Strereospecific degradation of dodemorph by bacteria. 
[5], moreover, they can disturb the semipermeability of plasmalemma by selectively coupling to phospholipids [6] and alter the activity of $\mathrm{Mg}^{2+}$-dependent ATP-ases as well [7]. Their use was declined after discovery of benzimidazole [8] [9] and triazole fungicides [10], however, due to rapid development of acquired tolerance to highly specific monosite inhibitors in populations of target microbes, the importance of morpholines is recently increasing. The morpholine fungicides exhibit activity against Gram positive bacteria [2] and some Gram negative species [11] [12] being stereospecific in most of cases [13].

The aim of these studies was to elucidate the importance of stereochemistry of the methyl groups on morpholine ring (Figure 1) with special regard to possible consequences in fungicidal performance of dodemorph.

\section{Materials and Methods}

\subsection{Compounds and Microbes Tested}

Marketed products, Calixin 75 ec (tridemorph, CASN: 24602-86-6), Corbel 75 ec (fenpropimorph, CASN: 67564-91-4) and Meltatox 40 ec (dodemorph, CASN: 1593-77-7) as well as their active substances were used for testing antimicrobial activities. The analytical standards were gifted by producer (BASF, Ludwigshafen, BRD).

The diastereomers were isolated as follows: Appropriate amount of formulation ( $4 \mathrm{~g}$ of suspected active substance) was added to aqueous sodium carbonate $(15 \% \mathrm{w} / \mathrm{v} ; 100 \mathrm{~mL})$ and the mixture shaken with ethylacetate + cyclohexane (1:1 $\mathrm{v} / \mathrm{v} ; 200 \mathrm{~mL})$. The organic phase was removed and treated with active carbon $(200 \mathrm{mg})$ and magnesium sulphate $(5 \mathrm{~g})$, then the volume was reduced to $15 \mathrm{~mL}$ in rotary evaporator. This mixture was subjected to column chromatography on Kieselgel $\mathrm{H}$, the diastereomers being eluted with dichloroethane + cyclohexanone + ethylacetate + acetone $(48+50+10+2$ by volume $)$, and were identified by their physicochemical characteristics [10].

The microbes used in toxicity were of the collection of Plant Protection Institute HAS (WDCM824).
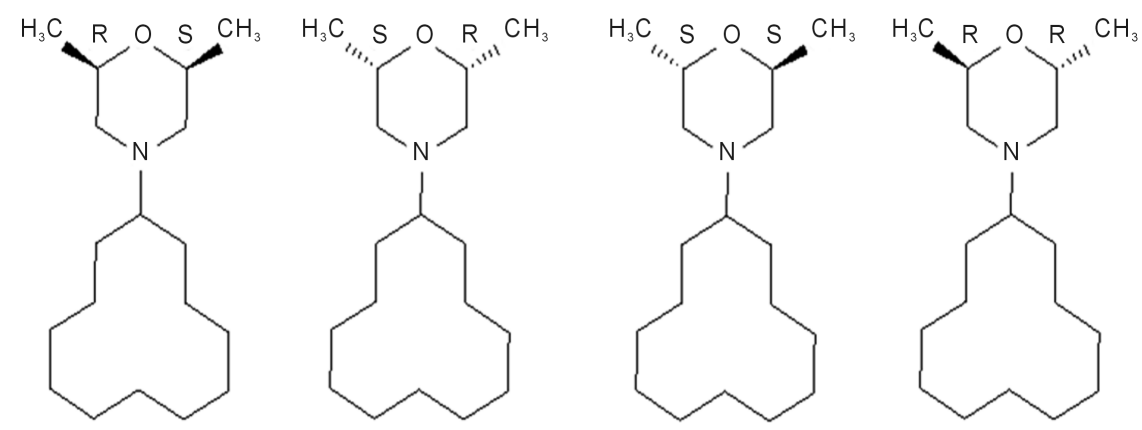

Figure 1. Enanthiomers of dodemorph. ACD ChemScetch 2012 was used as graphic tool for drawing and stereochemical labeling. Only one enanthiomer $(R S)$ exists in the case of $c i s$-(diequatorial)-diastereomer (meso-form) due to inner symmetry at $N \rightarrow O$ axis in morpholine ring, contrary to trans-(axialequatorial)-form, which has two enanthiomers (SS and $R R$, respectively). 


\subsection{Toxicity Tests}

The bacteria (listed in Table 1) were maintained on nutrient agar slants and cultured in nutrient broth containing Bacto peptone, Yeast extract (Difco), glucose and glycerol (10, 1, 3 and $1 \mathrm{~g} \cdot \mathrm{L}^{-1}$, respectively) and $\mathrm{KH}_{2} \mathrm{PO}_{4}, \mathrm{KCl}, \mathrm{MgSO}_{4}$, $\mathrm{CaCl}_{2}, \mathrm{NaCl}$ and $\mathrm{Fe}^{3+}$ citrate $\left(0.55,0.425,0.125 .0 .125,0.1\right.$ and $0.005 \mathrm{~g} \cdot \mathrm{L}^{-1}$, respectively). Hoagland Arnon's micoelement solution was also added ( $1 \mathrm{~mL}$ pro $1 \mathrm{~L}$ ). Solid media were prepared by incorporating agar-agar (Oxoid; $15 \mathrm{~g} \cdot \mathrm{L}^{-1}$ ) into this solution.

Standardized bacterial suspensions for minimal inhibitory concentrations (MIC), and "degradation" tests were prepared by washing cells from $20 \mathrm{~h}$ old culture on solid medium ( $5 \mathrm{~mL}$ in a tube) with sterile liquid medium $(5 \mathrm{~mL})$. The optical density of the suspensions was determined (520 nm; Unicam SP 800) and water than added to give a final $\mathrm{OD}_{600}$ of $0.4-0.5$. Such suspensions were prepared for each species tested, and added to wells of multipoint inoculator cooled to $1^{\circ} \mathrm{C}-4^{\circ} \mathrm{C}$.

Minimum inhibitory concentrations for bacteria were determined by adding the appropriate compound in sterile distilled water to nutrient agar $(30 \mathrm{~mL}$; $45^{\circ} \mathrm{C}$ ), mixing well and dispensing aliquots of the resultant mixture into each of two Petri dishes. These were inculcated with the standard suspension of the appropriate bacteria using a multipoint inoculator. Dishes were incubated $\left(25^{\circ} \mathrm{C}\right.$ $\pm 2^{\circ} \mathrm{C}$ ) and bacterial growth evaluated after 48 and 96 hours on the scale $1-4$, where 1 represented stimulation, 2 similar to and 3 retardation of growth compared with that on the control and 4 represented no growth. A series of concentration $\left(1000 / 2^{\mathrm{n}} \mathrm{mg} \cdot \mathrm{L}^{-1}, \mathrm{n}=0,1,2, \ldots, 21\right)$ were tested.

The fungi, Aspergillus niger van Tiegh., Fusarium graminearum Schwabe, $F$. oxysporum Schlechtendahl, Chaetomium globosum Kunze, Botrytis cinerea Pers., Thielaviopsis basicola (Berk. \& Broome) Ferraris, Rhizoctonia solani Kühn, Trametes versicolor (L.) Lloyd, Pythium irregulare Buisman and Phytophthora cactorum Pethyb. were maintained and cultured on home prepared potato dextrose agar (PDA) slants amended with mineral salts listed above and sodium nitrate $\left(2 \mathrm{~g} \cdot \mathrm{L}^{-1}\right)$. The broth was prepared from peeled potato tubers $(200 \mathrm{~g})$ cut into pieces (approx. $1 \times 1 \times 1 \mathrm{~cm}$ ) and cooked in 1 litre of distilled water $(20 \mathrm{~min}$ ) then filtered through a Perlon meshwork (No. 500) and the filtrate was then made up to 1 litre with distilled water.

The fungictoxicity of compounds was characterized by $\mathrm{ED}_{50}$ values $\left(\mathrm{mg} \cdot \mathrm{L}^{-1}\right)$, calculated from radial growth inhibition rates expressed as percentage of control grown on poison free medium. The synergetic character of joint action of diastereomers was tested according to either Colby [14] or Sun [15]. The comparative toxicity index (Co.T.I.) was calculated using $\mathrm{ED}_{50}$ values as follows: Co.T.I. $=(1 / \mathrm{F}) /((a / C)+(b / T))$, where $\mathrm{F}, \mathrm{C}$ and $\mathrm{T}$ are the $\mathrm{ED}_{50}$ values of the commercial product $(\mathrm{F})$ and single diastereomers $(\mathrm{T}=$ trans- and $\mathrm{C}=$ $c i s-$, and $a$ and $b$ their weight ratios in the active ingredient of marketed fungicide. 


\subsection{Degradation Experiments}

Standard suspension of bacteria $(5 \mathrm{~mL})$ was added to nutrient broth $(150 \mathrm{~mL})$ in $500 \mathrm{~mL}$ Erlenmeyer flask and the whole incubated on a rotary shaker at $24^{\circ} \mathrm{C}$ for 22 hours ( $A$ tumefaciens, E. uredovora, $P$. fluorescens and $X$. vesicatoria) or 44 hours $(C$. betae). The resulted suspensions were centrifuged (10 $\mathrm{min}, 9000 \mathrm{~g})$, the pellet washed with sterile medium (without peptone and yeast extract), and the residue weighed. All operations were performed at $0^{\circ} \mathrm{C}-1^{\circ} \mathrm{C}$, and the medium was adjusted to $\mathrm{pH} 6.8$ prior use. A portion of the cells (500 mg) was added to the medium ( $25 \mathrm{~mL}$, without peptone and yeast extract) to give the working suspension used for studies of partition coefficient and degradation.

The acetonous stock solution of the appropriate compound (500 $\mu \mathrm{g})$ as added to the working suspension, mixed well, and the suspension incubated on a rotary shaker at $27^{\circ} \mathrm{C} \pm 1^{\circ} \mathrm{C}$ for 5 hours. The suspension was then cooled melting ice bath to $0^{\circ} \mathrm{C}$ and centrifuged $\left(10 \mathrm{~min}, 9000 \mathrm{~g}\right.$ ) at $0^{\circ} \mathrm{C}-1^{\circ} \mathrm{C}$. The supernatant and residual bacteria were analyzed separately.

\subsection{Analytical Techniques}

Silufol $\mathrm{UV}_{254}$ plates (Cavalier, Votice, Bohemia) with benzene + ethylacetate (78 $+22 \mathrm{v} / \mathrm{v}$ ) as mobile phase were used for purity test, where diastereomers were visualized with iodine vapor as well, the minimum quantity detectable being 0.1 $\mu \mathrm{g}\left(10^{-6} \mathrm{mM}\right)$.

Packard series 7400 instrument equipped with a flame ionization detector, and $180 \times 2 \mathrm{~mm}$ I.O. glass column packed with $3 \% \mathrm{OV}-1+1.5 \% \mathrm{OV}-225$ on Gaschrom Q (80 - 100 mesh) were used for separation of diastereomers. The detector and injector temperatures were $235^{\circ} \mathrm{C}$. The column temperature was changed at $10^{\circ} \mathrm{C} \mathrm{min}^{-1}$ from $150^{\circ} \mathrm{C}$ to $220^{\circ} \mathrm{C}$ after $4 \mathrm{~min}$ initial hold and $9 \mathrm{~min}$ final hold. $5 \times 10^{-6} \mathrm{~g}$ of compound were injected in 5 microlitre, final resolution power $3 \times 10^{-9}$ as the final point of the calibration curve.

For determination of the quantity of test compounds in medium of degradation experiments $0.5 \mathrm{~mL}$ acetone and $2 \mathrm{~mL}$ saturated sodium sulphate containing $5 \% \mathrm{v} / \mathrm{w}$ sodium carbonate was added to the supernatant, which was then extracted with $1.0 \mathrm{~mL}$ of cyclohexanone + ethylacetate + toluene $(5+1+5 \mathrm{v} / \mathrm{v})$ and the organic phase used for GC analysis immediately. The degradation rate was calculated from the analytical data as a difference of test substances applied and that in the supernatant and in the bacteria after 5 hours incubation.

The bacterial residue was suspended in distilled water $(0.5 \mathrm{~mL})$, then acetone $(0.5 \mathrm{~mL})$ added and the mixture kept in boiling water for $3 \mathrm{~min}$. Distilled water saturated with sodium chloride $(4 \mathrm{~mL})$ were than added, and the resulting suspension extracted as above. The organic phase was subsequently analyzed by GC. The distribution of test chemicals between bacterial cells and medium was expressed as K;

$\mathrm{K}=[$ concentration $(\mathrm{microg} / \mathrm{g})$ in the cell $] /[$ concentration $(\mathrm{microg} / \mathrm{mL})$ in the medium] 
and $\mathrm{K}$ was a measure of uptake of the investigated substance into the cells.

\subsection{Data Treatment}

All experiments were carried out at least in triplicates. Student's $t$ was used to evaluate significance of differences between average values, and Fisher's test was applied to reveal impact of alterations in structure of test compounds at $\mathrm{P}=5 \%$ level.

\section{Results and Discussion}

\subsection{Toxicity}

Meltatox proved to be most effective against bacteria surpassing Calixin or Corbel (Table 1). In general, the Gram positive bacteria were essentially more sensitive to morpholine fungicides than Gram negatives. Although, no data are available for the intrinsic activities of formulants, seemingly all test microbes tolerated well the carriers used for preparation as only at high concentrations were revealed minuscule differences between commercial products and their active ingredients. The diastereomers had different toxicities (Table 1). The most effective cis-form seems to be responsible for the toxicity of formulated product, Meltatox $40 \mathrm{ec}$, Agrobacterium, Erwinia and Pseudomomas spp. The cis-form is also more toxic to Xanthomonas species, while Gram positives exhibited differential sensitivity.

Differential sensitivity was also demonstrated among fungal species investigated in vitro (Table 2). Calixin $75 \mathrm{ec}$ was most toxic to the majority of fungi, while Meltatox 40ec and the constituent dodemorph diastereomers proved to be the least toxic. Although, in several cases significant difference of activity could not be revealed between diastereomers, their mixtures always exhibited higher toxicity. The synergy varied within large limits, and it was outstanding in the case of $B$. cinerea. The stereoselective antifungal activity is not a proper character of dodemorph as it was similarly elucidated in the case of tridemorph diasteremers as well.

\subsection{Uptake of Diastereomers into Bacterial Cells}

Uptake of diastereomers into bacterial cells was very different with the representatives of the five genera tested and seems to be proportional to their sensitivity (Table 3). The trans-form was accumulated much more than the cis-form and the ratio varied a little. This enrichment with a particular diastereomer was inversely correlated with lipophilicity over a range of $\mathrm{pH}$. The cis-form is $2-4$ times more lipophilic than the trans one. Cells of these bacteria are surrounded with a hydrophilic capsule having acidic character. This capsule is clearly the first barrier to permeation of the molecules into the cells. Perhaps this is the cause of the inverse correlation between the lipophilicity of dodemorph isomers and their accumulation in the cells. The effect of cell wall and mucous capsule can be possibly influenced by the change of the $\mathrm{pH}$ which depending on the 
Table 1. Growth inhibitory effect of morpholine derivatives towards bacteria.

\begin{tabular}{|c|c|c|c|c|c|c|}
\hline \multirow{3}{*}{ Bacteria } & \multicolumn{6}{|c|}{ Minimum inhibitory concntrations $\left(\mathrm{mg} \cdot \mathrm{L}^{-1}\right)$} \\
\hline & \multicolumn{2}{|c|}{ Dodemorph } & \multicolumn{2}{|c|}{ Tridemorph } & \multirow{2}{*}{$\begin{array}{l}\text { Fenpropi- } \\
\text { morph- }\end{array}$} & \multirow{2}{*}{$\begin{array}{c}\text { Strepto. } \\
\text { mycin }\end{array}$} \\
\hline & cis- & trans- & cis- & trans- & & \\
\hline \multicolumn{7}{|l|}{ Agrobacterium } \\
\hline A. radiobacter $\mathrm{K}-84$ & $125-250$ & $>1000$ & $250-500$ & $250-500$ & $>1000$ & $>1000$ \\
\hline A. tumefaciens $\mathrm{C}-58$ & $62-125$ & $>1000$ & $125-250$ & $250-500$ & $>1000$ & $62-125$ \\
\hline A. tumefaciens $\mathrm{O}$ & $125-250$ & $>1000$ & $125-250$ & $250-500$ & $>1000$ & $>1000$ \\
\hline \multicolumn{7}{|l|}{ Bradyrhizobium } \\
\hline B. japonicum 27 & $125-250$ & $>1000$ & $31-62$ & $62-125$ & $>1000$ & $>1000$ \\
\hline \multicolumn{7}{|l|}{ Rhizobium } \\
\hline R. trifolii 28 & $250-500$ & $>1000$ & $500-1000$ & $500-1000$ & $>1000$ & $>1000$ \\
\hline \multicolumn{7}{|l|}{ Erwinia } \\
\hline E. atroseptica & $125-250$ & $>1000$ & $31-62$ & $31-125$ & $>1000$ & $125-250$ \\
\hline E. carotovora & $>1000$ & $>1000$ & $31-62$ & $15-31$ & $>1000$ & $125-250$ \\
\hline E. chrysanthemi $\mathrm{B} 8$ & $500-1000$ & $>1000$ & $500-1000$ & $500-1000$ & $>1000$ & $1-2$ \\
\hline E. herbicola D-5 & $62-125$ & $>1000$ & $125-250$ & $125-250$ & $>1000$ & $31-62$ \\
\hline E. uredovora $3 \mathrm{vfr}$ & $500-1000$ & $>1000$ & $250-500$ & $500-1000$ & $>1000$ & $8-16$ \\
\hline \multicolumn{7}{|l|}{ Pseudomonas } \\
\hline P. fluorescens K-20 & $500-1000$ & $>1000$ & $500-1000$ & $500-1000$ & $>1000$ & $16-31$ \\
\hline P. lachrymans 12 & $>1000$ & $>1000$ & $125-250$ & $250-500$ & $>1000$ & $1-2$ \\
\hline P. phaseolicola 14 & $>1000$ & $>1000$ & $125-250$ & $16-31$ & $>1000$ & $>1000$ \\
\hline \multicolumn{7}{|l|}{ Xanthomonas } \\
\hline$X$. alfalfae KK-1 & $250-500$ & $500-1000$ & $125-250$ & $250-500$ & $>1000$ & $4-8$ \\
\hline$X$. campestris $2 \mathrm{D} 510$ & $125-250$ & $16-31$ & $62-125$ & $125-250$ & $500-1000$ & $16-31$ \\
\hline$X \cdot$ pelargonii 58 & $8-16$ & $8-16$ & $31-62$ & $125-250$ & $62-15$ & $16-31$ \\
\hline$X$. vesicatoria 53 & $125-250$ & $250-500$ & $125-250$ & $125-250$ & $>1000$ & $16-31$ \\
\hline \multicolumn{7}{|l|}{ Corynebacterium } \\
\hline C. betae 101 & $31-62$ & $8-16$ & $31-62$ & $31-62$ & $31-62$ & n.t. \\
\hline C. fascians 27 & $1-2$ & $0.01-4$ & $16-31$ & $16-31$ & $31-62$ & $62-125$ \\
\hline C. flaccumfaciens 8 & $62-125$ & $62-125$ & $16-31$ & $31-62$ & $31-62$ & $16-31$ \\
\hline C. michiganense 9 & $4-8$ & $0.1-0.2$ & $2-4$ & $8-16$ & $31-62$ & $1-2$ \\
\hline C. nebraskense 101 & $4-9$ & $0.5-1$ & $2-4$ & $16-31$ & $31-62$ & $125-250$ \\
\hline C. oortii 11 & $8-16$ & $16-31$ & $8-16$ & $31-62$ & $31-62$ & $16-31$ \\
\hline
\end{tabular}

Code numbers of Agrobacterium, Bradyrhizobium, Rhizobium, Erwinia, Pseudomonas, Xanthomonas and Corynebacterium strains were given by identifiers. n.t. $=$ not tested. 
Table 2. Inhibitory effect of morpholine fungicides and their diastereomers on the radial growth of fungi.

\begin{tabular}{|c|c|c|c|c|c|c|c|c|c|}
\hline \multirow{2}{*}{ Fungi } & \multirow{2}{*}{$\begin{array}{c}\text { Meltatox } \\
40 \mathrm{ec}\end{array}$} & \multicolumn{2}{|c|}{ Dodemorph } & \multirow{2}{*}{$\begin{array}{l}\text { Co. } \\
\text { T.I. }\end{array}$} & \multirow{2}{*}{$\begin{array}{c}\text { Calixin } \\
75 \mathrm{ec}\end{array}$} & \multicolumn{2}{|c|}{ Tridemorph } & \multirow{2}{*}{$\begin{array}{l}\text { Co. } \\
\text { T.I. }\end{array}$} & \multirow{2}{*}{$\begin{array}{c}\text { Corbel } \\
75 \mathrm{ec}\end{array}$} \\
\hline & & cis & trans & & & cis & trans & & \\
\hline P. irregulare & 32.7 & 60.5 & 21.2 & 1.1 & 27.0 & 34.9 & 60.7 & 1.7 & 58.2 \\
\hline P. cactorum & 178.7 & 890.1 & 89.0 & 1.1 & 3.6 & 23.1 & 41.3 & 8.5 & 26.5 \\
\hline A. niger & 151.4 & 572.0 & 223.6 & 2.3 & 3.8 & 8.6 & 8.2 & 2.2 & 8.7 \\
\hline F. graminear. & 38.0 & 77.4 & 70.6 & 2.0 & 14.5 & 39.3 & 29.0 & 2.3 & 9.7 \\
\hline F. oxysporum & 43.7 & 112.1 & 122.9 & 2.7 & 6.8 & 35.8 & 32.6 & 5.0 & 27.5 \\
\hline C. globosum & 7.94 & 70.70 & 50.10 & 7.65 & 1.86 & 2.18 & 5.83 & 1.79 & 0.76 \\
\hline B. cinerea & 0.33 & 7.8 & 14.8 & 28.9 & 0.31 & 1.5 & 2.0 & 5.5 & 0.2 \\
\hline T. basicola & 17.4 & 60.2 & 72.3 & 3.7 & 1.1 & 3.6 & 5.4 & 4.1 & 1.8 \\
\hline R. solani & 3.6 & 7.8 & 4.5 & 1.6 & 1.0 & 3.2 & 4.5 & 3.9 & 0.15 \\
\hline T. versicolor & 5.0 & 7.8 & 30.9 & 2.2 & 0.64 & 0.90 & 3.0 & 2.3 & 0.19 \\
\hline
\end{tabular}

The body of the table comprises $\mathrm{ED}_{50}$ values $\left(\mathrm{mg} \cdot \mathrm{L}^{-1}\right)$ and comparative toxicity indices characterizing the joint action of diastereomers. Corbel $75 \mathrm{ec}$ containes only cis-fenpropimorph. Example for calculating Co. T.I $=(1 / 0.33) /((0.6 / 7.8)+(0.4 / 14.8))=28.9$ in the case of $B$. cinerea. The joint action is synergic when Co. T.I. $>1.0$, and antagonistic when Co. T.I. $<1.0$, while the effect is considered to be additive when Co. T.I. $=1 \pm 0.05$.

Table 3. Uptake and degradation of dodemorph diastereomes in bacterial suspension.

\begin{tabular}{|c|c|c|c|c|c|c|c|}
\hline \multirow{2}{*}{ Parameters } & \multirow{2}{*}{ Isomers } & \multicolumn{5}{|c|}{ Bacteria $^{\mathrm{a}}$} & \multirow{2}{*}{$\mathrm{LSD}_{0.05}$} \\
\hline & & $\mathrm{A}$ & $\mathrm{E}$ & $\mathrm{P}$ & $\mathrm{X}$ & $\mathrm{C}$ & \\
\hline \multicolumn{8}{|c|}{ Measured quantity $(\mu \mathrm{g})$ in } \\
\hline \multirow[t]{3}{*}{ Cells } & $c i s-\mathrm{D}$ & 66.5 & 24.8 & 21.5 & 66.9 & 156.9 & 4.94 \\
\hline & trans-D & 91.8 & 46.1 & 77.5 & 96.5 & 174.6 & \\
\hline & $\mathrm{c} / \mathrm{t}$ & 0.72 & 0.54 & 0.28 & 0.69 & 0.90 & \\
\hline \multirow[t]{3}{*}{ Medium } & $c i s-\mathrm{D}$ & 45.6 & 207.4 & 187.2 & 94.2 & 36.1 & 4.94 \\
\hline & trans-D & 22.4 & 159.1 & 116.5 & 47.1 & 16.2 & \\
\hline & $c / t$ & 2.04 & 1.3 & 1.61 & 2.00 & 2.23 & \\
\hline \multicolumn{8}{|c|}{ Distribution $(\mathrm{K}=[$ cell $] /[$ medium $])$} \\
\hline & trans-D & 81.6 & 5.8 & 12.8 & 40.9 & 216.1 & 1.49 \\
\hline & $\mathrm{c} / \mathrm{t}$ & 0.36 & 0.41 & 0.18 & 0.35 & 0.40 & \\
\hline \multicolumn{8}{|c|}{ Degradation ( $\mu \mathrm{g} / \mathrm{g}$ cells/hour) } \\
\hline & $c i s-\mathrm{D}$ & 162.9 & 42.7 & 66.3 & 113.9 & 81.9 & 21.9 \\
\hline & trans-D & 110.7 & 19.8 & 34.1 & 81.8 & 34.2 & \\
\hline & $\mathrm{c} / \mathrm{t}$ & 1.47 & 2.16 & 1.94 & 1.39 & 2.39 & \\
\hline \multicolumn{8}{|c|}{ Ratio of ionized diastereomers $(\%)^{\mathrm{b}}$} \\
\hline \multirow[t]{2}{*}{ Actual pH } & & 4.9 & 4.7 & 4.1 & 5.5 & 4.5 & \\
\hline & $c i s-\mathrm{D}$ & 98.32 & 98.84 & 99.68 & 93.5 & 99.31 & \\
\hline
\end{tabular}

${ }^{a} A$. tumefaciens C58, E. carotovora, $P$. fluorescens, $X$. vesicatoria and $C$. betae were used for experiments. ${ }^{\mathrm{b}}$ The medium was acidified during the incubation at species dependent manner. The $\mathrm{pH}$ of the bacterium suspensions was 6.8 at the start of incubation, and the degree of ionization was 50 and $28.9 \%$ of $c i s-$ and trans-diastereomers, respectively. 
species drops during the incubation from the original 6.8 to $4.1-5.5$. We can suppose the existence of $\mathrm{pH}$ gradient (changing during incubation) via medium/outside of mucous capsule to inner side of plasmalemma, which can change the degree of ionization of capsule-cell wall and both diastereomers. In the last case the change of $\mathrm{pH}$ in the medium moves the ratio of cationic form from about $25 \%$ to $80 \%$ - $99 \%$ in dependence of the species and diastereomeric form concerned $\left(\mathrm{pK}_{\mathrm{b}}\right.$ values for cis- and trans-forms are 6.66 and 6.29, respectively). As the difference between accumulation of cis- and trans-forms much higher than the difference between their ionization in each proper case, we can suppose, that the selective "accumulation" observed was not due to the fact, that the increased ionization upraises the possibility of bounding a cation, so the inverse "lipophilicity" correlation is not an artifact.

\subsection{Degradation}

The quantity of both diastereomers was diminished by bacteria in the incubation system during a 5 hours incubation. This phenomenon we could detect only in case of intact cells. For this we suggest that it is the result of the transformation, character of what we did not investigate, because of the instability of the compounds of degradation, however, the original molecules we could resolve with high degree. This made possible to extract information from the analytical data about degradation as the diminishing of quantity can be calculated, that means, the lack of the total quantity of the substance is an indirect characteristic of the transformation activity in bacteria. Degradation rates in absence of stereospecificity should correspond to the original ratio of diastereomers.

Differences in accumulation of individual isomers per se cause alteration in ratio (cis[RS]/trans[RR]/trans[SS]) of $(3+3+2+2)$ or (cis[R,S] versus trans $[R R, S S])$ of 3:2. The ratios calculated from the measured values did not correspond to the original one that was altered to the side of lower values speaking about the more rapid transformation of the more active cis( $\mathrm{R}, \mathrm{S})$-form (Table 3 ). This suggests that the degradation in bacteria means detoxification. The transformation systems of investigated bacterial species distinguished the diastereomers in various degrees, unfortunately, we could not determine the possible change of ratios of RR/SS enanthiomers of trans-form. From measured values after 5 hours incubation it can be supposed, that one of them is more rapidly transformed during $5 \mathrm{hrs}$ of incubation because of the absence of transformation rate significantly more than $50 \%$ of transformation.

The cis-isomer was significantly more active than the trans one $\left(\mathrm{t}_{\mathrm{C}, \mathrm{T}}=7.72, \mathrm{p}\right.$ $<0.05)$, nevertheless, their ratio in commercial product $(3 \mathrm{C}+2 \mathrm{~T})$ resulted synergic effect in the case of numerous fungi (Table 2) that can influence significantly the fungicidal performance of marketed product.

The biodegradation not only diminishes the quantity of dodemorph applied, but this stereoselective metabolic process also leads to changes in the ratio of synergicaly interacting diastereomers. Two optimal mixtures with dominating either cis- or trans-diastereomers were found as evaluated with B. cinerea (Figure 2). 
The growth inhibitory effect of 9:1 and 3:7 cis/trans mixtures did not differed significantly $(47.1 \pm 2.4$ and $45.6 \% \pm 3.2 \%$, respectively, $\mathrm{t}=0.74, \mathrm{p}>0.1)$, and the increase was economically acceptable in both cases. Thus, the most rapid degradation of cis-form as compared to trans-form does not result decreased efficacy of treatment, as the alteration of their ratio of 3:2 to domination of trans-form leads to increase of fungicidal activity, that means, the stereoselective deterioration by bacteria may be presumed as a special type of biactivation. Similar interaction could be revealed between $N$-alkyl derivatives as well, and the mixtures of corresponding dodemorph and tridemorph diastereomers also formed synergic compositions.

\subsection{Future Prospects}

The development of molecular design opened possibility to reinvestigate the structure/activity relationships of morpholine derivatives, which have special place among systemic fungicides due to lack of acquired tolerance in populations of target phytopathogens. The main targets in filamentous fungi are in steroid metabolism, however, their antimicrobial activity relates also to inhibition of

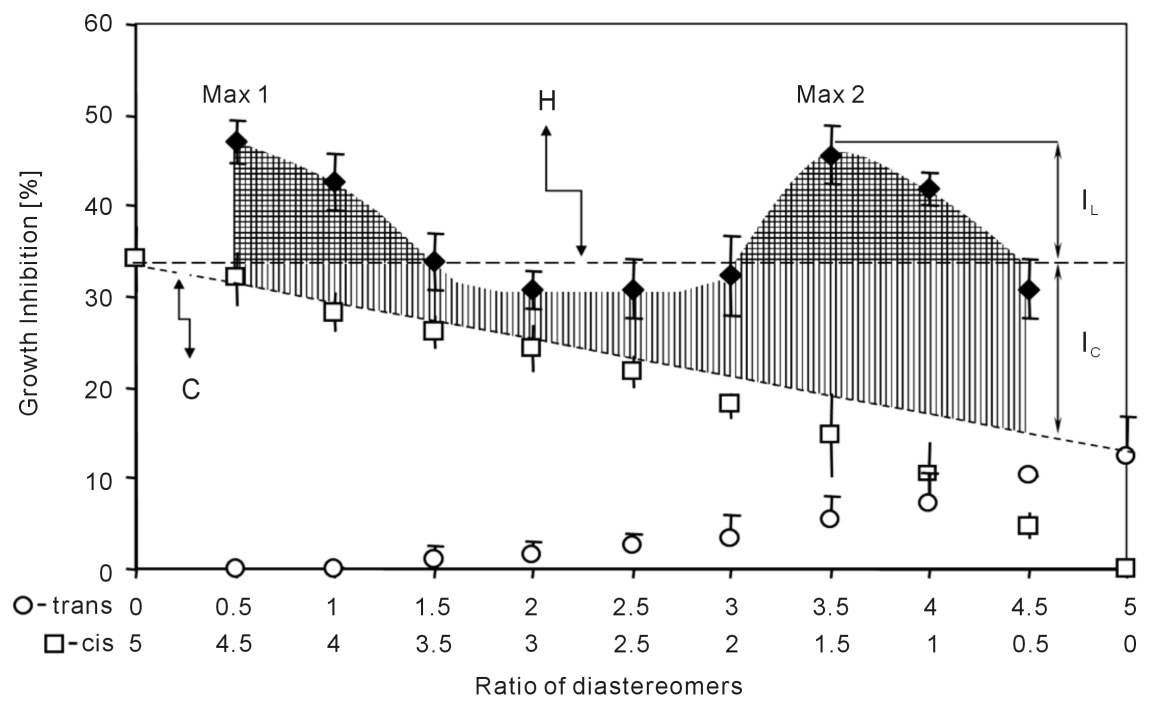

Figure 2. Evaluation of joint action of dodemorph diastereomers against benomyl tolerant Botrytis cinerea. The experimental model of Horsfall (1945) was applied at $5 \mathrm{mg} \cdot \mathrm{L}^{-1}$ of active ingredient in the PDA. Lines $\mathrm{C}$ and $\mathrm{H}$ mark additive effect calculated according to Colby [14] and requested minimum increase in efficacy of mixture requested by re Lemin's case [16], respectively. $I_{L}$ is the maximum increase in efficacy of mixtures evaluated by Horsfall's model [17] and accepted by US Patent Office as economically approved synergy, while $\mathrm{I}_{\mathrm{C}}$ is the part of efficacy over additive that does not add significant economic benefit when the two compounds applied in mixture $\left(\mathrm{t}_{\mathrm{C} 10, \mathrm{C} 7+\mathrm{T} 3}=0.15, \mathrm{t}_{\mathrm{C} 5, \mathrm{C} 3+\mathrm{T} 2}=1.57, \mathrm{t}_{\mathrm{C} 10, \mathrm{C} 5+\mathrm{T} 5}=\right.$ $\left.1.36, \mathrm{t}_{\mathrm{C} 3+\mathrm{T} 2}=0.65, \mathrm{t}_{\mathrm{C} 10, \mathrm{C} 1+\mathrm{T} 9}=1.36<\mathrm{t}_{0.1}=2.35\right)$, according to decision of Worley et al. [16]. Example for evaluation expected activity of Meltatox $40 \mathrm{ec}(3$ cis +2 trans diastereomers) at 5 $\mathrm{mg} \cdot \mathrm{L}^{-1}$ by Colby's model [14]: The expected activity $=\mathrm{C}+\mathrm{T}-(\mathrm{C} \times \mathrm{T} / 100)=24.3+1.5-$ $\left(\left(24.3^{*} 1.5\right) / 100\right)=25.4 \%$, but the measured one was $30.9 \%$ that is $5.5 \%$ more than the expected. However, this synergic increase in efficacy does not result economic benefit because the cis-form resulted $34.2 \%$ inhibition when applied alone. 
various other target sites in metabolism and cell membrane, which can explain their antibacterial activity. Moreover, tridemorph applied in combination with $\mathrm{P}_{450}$ inducer changed the character of host/parasite relationship converting the symptomless sensitive state of plant cells to hypersensitive [7] in the case obligate endoparasites. The mechanisms of cell/cell interaction and nutrition of archeas residing in plants are white fields, but these pathogens might be target organisms to morpholine derivatives as phospholipids selectively interact with these compounds [6]. The special advantage of this group is the lack of their accumulation in the environment or in the food chain due to rapid biodegradation of morpholine derivatives.

\section{Conclusion}

Interaction between dodemorph disastereomers against bacteria could not be revealed, while the synergic joint action essentially influences the fungitoxic action of the formulated product (Meltatox 40ec) containing their mixture. The stereoselective biodegradation of diastereomers in the case of these compounds is a special type of activation that significantly improves the antifungal performance of dodemorph.

\section{Acknowledgements}

This research work was supported by Chinoin Pharmaceutial Company, Budapest, Hungary.

\section{References}

[1] König, K.-H., Pommer, E.-H. and Sanne, W. (1965) N-Substituted Tetrahydro-1,4Oxazines, New Class of Fungicidal Compounds. Angewandte Chemie, 4, 336-341. https://doi.org/10.1002/anie.196503361

[2] Kerkenaar, A. and Sijpesteijn, A.K. (1979) On the Antifungal Mode of Action of Tridemorph. Pesticide Biochemistry and Physiology, 12, 195-204. https://doi.org/10.1016/0048-3575(79)90102-0

[3] Roobina, I., Baloch, E., Mercer, I., Thomas, E., Wiggins, B. and Baldwin, C. (1984) Inhibition of Ergosterol Biosynthesis in Saccharomyces cerevisiae and Ustilago maydis by Tridemorph, Fenpropimorph and Fenpropidin. Phytochemistry, 23, 2219-2219. https://doi.org/10.1016/S0031-9422(00)80523-3

[4] Baloch, R.I. and Mercer, E.I. (1987) Inhibition of Sterol $\Delta 8 \rightarrow \Delta 7$-Isomerase and $\Delta 14$-Reductase by Fenpropimorph, Tridemorph and Fenpropidin in Cell-Free Enzyme Systems from Saccharomyces cerevisiae. Phytochemistry, 26, 663-668. https://doi.org/10.1016/S0031-9422(00)84762-7

[5] Rekka, E.A., Kourounakis, P.A., Avramidis, N. and Kourounakis, P.N. (2005) Effect of Some Biologically Interesting Substituted Tetrahydro-1,4-Oxazines on Drug Metabolising Enzymes and on Inflammation. Current Drug Metabolism, 6, 481-485. https://doi.org/10.2174/138920005774330648

[6] Oros, G., Cserháti, T. and Szôgyi, M. (1988) Correlation between Biological Activity and Membrane Damaging Effect of Some Morpholine Derivative Fungicides. XIVth International Congress of Biochemistry, July 11-15 1988, Prague, Vol. 1, 138.

[7] Oros, G. (1991) Effects of 2,6-Dimethylmorpholine Derivative Fungicides on Pro- 
and Eukaryotes. Ph.D. Thesis, HAS, Budapest, 163.

[8] Robinson, H.J., Phares, H.T. and Graessle, O.E. (1964) Antimycotic Properties of Thiabendazole. Journal of Investigative Dermatology, 42, 479-482. https://doi.org/10.1038/jid.1964.101

[9] Delp, C.J. and Klopping, H.L. (1968) Performane Attributes of New Fungicide and Mite Ovidie Candidate. Plant Disease Reporter, 52, 95.

[10] Worthing, C.R. (1979) Pesticide Manual. 6th Edition, British Crop Protection Council, London, U.K.

[11] Süle, S. and Oros, G. (1980) A Calixin egy kevéssé ismert hatásáról. Agrártudományi Közlemények, 39, 112.

[12] Oros, G. and Süle, S. (1982) Antibacterial Activity of Calixin on Phytopathogenic Bacteria. Abhandlungen der Akademie der Wissenschaften der DDR Series D, No. 2001, Akademie Verlag, Berlin, 417-420.

[13] Oros, G. (1983) Stereospecific Degradation of Dodemorph Isomers by Various Phytopathogenic Bacteria. The Symposium Ergosterol Biosynthesis Inhibitors, March 22-24 1983, Reading, Abstract. No. 43. The Pesticides Group and the Physicochemical and Biophysical Panel, Society of Chemical Industry.

[14] Colby, S.R. (1967) Calculating Synergistic and Antagonistic Responses of Herbicide Combinations. Weeds, 15, 20-22. https://doi.org/10.2307/4041058

[15] Sun, Y.-P. (1950) Toxicity Index, an Improved Method of Comparing the Relative Toxicity of Insecticides. Journal of Economic Entomology, 43, 45-53. https://doi.org/10.1093/jee/43.1.45

[16] Worley, C.J., Rich, A. and Baldwin, A.J. (1969) Decision of the Court of Customs and Patent Appeals in re Lemin, Steinhards and Swank, No. 8127.

[17] Horsfall, J.G. and Dimmond, A.E. (1941) Role of Dosage-Response Curve in the Evaluation of Fungicides. Connecticut Experimental Station Bulletin, 451, 635-667. 